\title{
Is the labor market vulnerability of less-educated men really about job competition? New insights from the United States
}

\author{
Maurice Gesthuizen • Heike Solga
}

Accepted: 9 March 2013 / Published online: 28 March 2013

(C) Institut für Arbeitsmarkt- und Berufsforschung 2013

\begin{abstract}
There are various reasons why less-educated men have higher risks of labor market vulnerability—risks such as being unemployed or, if employed, having only low socioeconomic status. The commonly used argument is that these higher risks result from increased job competition caused by an oversupply of higher educated workers, who displace the less-educated from their jobs. In addition to exploring this argument, we investigate the impact of lesseducated men's cognitive skills, their social resources, and the (historically embedded) signaling value of not having educational credentials. We study this impact by using institutional and compositional variations across labor market entry cohorts in the United States. For our analyses, we use the data of the 1974-2008 US General Social Survey (GSS). They show that an oversupply of high-educated workers mainly increases the unemployment risks of the highereducated themselves. In labor market entry cohorts where the negative selection on parental background of the group of less-educated is more pronounced, the less-educated run a relatively high risk of unemployment.
\end{abstract}

JEL Classification J200 · L140 · J240 · I240

Dr. M. Gesthuizen $(\bowtie)$

Department of Sociology, Radboud University Nijmegen,

Thomas van Aquinostraat 4, room 01.54, P.O. Box 9104, 6500 HE Nijmegen, The Netherlands

e-mail: M.Gesthuizen@maw.ru.nl

Prof. Dr. H. Solga

Abteilung "Ausbildung und Arbeitsmarkt", Wissenschaftszentrum

Berlin für Sozialforschung (WZB), Reichpietschufer 50, 10785

Berlin, Germany

e-mail: solga@wzb.eu
Handelt es sich bei der Arbeitsmarktverwundbarkeit
schlechter ausgebildeter Männer wirklich um
beruflichen Wettbewerb? Neue Einblicke aus den USA

Zusammenfassung Es gibt verschiede Gründe, warum schlechter ausgebildete Männer höheren Risiken der Arbeitsmarktverwundbarkeit - Arbeitslosigkeitsrisiken oder bei Beschäftigten ein niedriger sozioökonomischer Status - unterliegen. Die gebräuchliche Erklärung hierfür ist, dass der Grund für diese höheren Risiken ein gesteigerter beruflicher Wettbewerb ist, der auf ein Überangebot an besser ausgebildeten Arbeitskräften zurückzuführen ist, die die schlechter ausgebildeten Arbeitskräfte aus ihren Beschäftigungen verdrängen. Zusätzlich zur Untersuchung dieser Erklärung analysieren wir den Einfluss der kognitiven Fähigkeiten schlechter ausgebildeter Männer, ihre sozialen Ressourcen und den (historisch eingebetteten) Signalwert, über keine Bildungsnachweise zu verfügen. Wir untersuchen diese Auswirkungen mittels institutioneller und kompositioneller Variationen über Arbeitsmarkt-Eintrittskohorten hinweg in den USA. Für unsere Analysen nutzen wir die Daten des 1974-2008 US General Social Survey (GSS). Sie zeigen, dass ein Überangebot an gut ausgebildeten Arbeitskräften hauptsächlich die Arbeitslosigkeitsrisiken der besser ausgebildeten Personen selbst steigert. In ArbeitsmarktEintrittskohorten, in welchen die negative Selektion basierend auf dem Hintergrund der Eltern der Gruppe der schlechter ausgebildeten deutlicher ist, haben die schlechter ausgebildeten ein relativ hohes Arbeitslosigkeitsrisiko.

\section{Introduction}

The fact that less-educated men are exposed to higher labor market risks is commonly explained by what is known 
as the displacement hypothesis: in times of intensified job competition, higher educated persons increasingly have to take up lower-skilled jobs, thereby displacing intermediateeducated workers from jobs previously available to them, who, in turn, crowd-out the less-educated workers from their jobs (Bills 1992; Blossfeld 1985; Gesthuizen and Wolbers 2010; Harrison and Weiss 1998; Kalleberg 1996). The core claim of this argument is that the employment opportunities of less-educated workers mainly depend on the labor supply-demand ratio. If there is an oversupply of higher educated workers, through a cascade effect the less-educated are eventually pushed into the most elementary jobs in the secondary labor market, or even into unemployment. Goldin and Katz (2008) recently proposed a similar argument when suggesting that wage differentials between skilled and unskilled workers are mainly driven by the supply of skilled labor.

The main weakness of the displacement argument is that the individual characteristics and the marginal productivity of the members of different education groups are conceptualized as being stable over time. It tends to disregard possible shifts that may occur as a result of changes in the educational system or educational expansion across labor market entry cohorts. Examples of such changes include alterations in the cognitive, non-cognitive, and social composition of education groups, as well as changes in the cultural meaning attached to specific educational credentials. Today, as most cohort members pursue higher education, lesseducated workers might have weaker social resources and cognitive and non-cognitive skills at their disposal than they did previously, when very few of their peers earned postsecondary degrees. In addition, the signal "low education" may project a more negative meaning if the less-educated group is a social minority. These shifts suggest that today's less-educated workers tend to have fewer social resources to support their job search, and that today's employers tend to be more reluctant to hire less-educated workers from more recent labor market entry cohorts-no matter what the current labor supply-demand ratio. Taking these objections together, it is clear that explanations of (long-term) changes in the employment opportunities of less-educated individuals have to take into account more than the variations in the labor supply-demand ratio. They also need to consider shifts in less-educated workers' social resources, cognitive skills, and non-cognitive skills (cf. Cappelli 1995; Gesthuizen et al. 2005; Solga 2002), as well as the cultural meaning of low education (Solga 2008). ${ }^{1}$

\footnotetext{
${ }^{1}$ Another weakness of the displacement argument is that it seems to assume that employers always prefer higher educated workers, even though they might be overqualified for the job. Employers, however, also fare well by having employees who are satisfied with their job and intend to commit themselves to the firm for a longer time. Longitudinal panel research actually shows that workers who are dissatisfied with
}

In this article, we will investigate whether, and if so how, the verbal skills of less-educated men, as well as the social composition of this education group, vary across labor market entry cohorts. Moreover, we will look at the extent to which these variations in cognitive and social composition, measured by verbal ability and parental socioeconomic status respectively, might help explain why less-educated men tend to face higher labor market risks across these different cohorts, as compared to intermediate-educated men in the same labor market entry cohort.

We will use the example of the United States-first because of the availability of suitable data (see below), second because it is a country that has seen a high degree of educational expansion, and third because it is a country with without vocational training system. The latter argument implies, firstly, that there is no occupation-specificity of secondary education, so that intermediate-educated persons also have to be trained on the job. And secondly, as we are studying labor market entry in an economy in which job skills are most notably learned on the job, educational (school) attainment should be a strong signal for trainability. The dominance of general schooling (instead of occupational certificates) as a signal for employers implies that stronger displacement should occur when competition intensifies. As a consequence, variation across cohorts should be pronounced, making the United States an interesting case for testing our hypotheses. By implication, in occupational labor markets such as in Germany, the processes described might be much less pronounced.

Labor market risks are measured by unemployment and, in if employed, by low socioeconomic status (SES). Concretely, we will answer the following research question: To what extent are differences in unemployment risks and socioeconomic status between less-educated and intermediateeducated people smaller or larger in labor market entry cohorts that vary in their high-skill supply-demand ratio (as an indicator of displacement), in the gap in verbal ability between the less- and intermediate-educated group (indicating negative cognitive selection), in the size of the less-educated group (indicating the cultural meaning of low education) and in the gap in parental socioeconomic status between the less- and intermediate-educated group (indicating negative social selection). Given that we theoretically expect negative cognitive and social selection to have increased over labor

the match between personal capabilities and the content of the job, are more likely to voluntarily change jobs, than workers who do not experience such a mismatch. This push factor is equally strong for lower and higher educated workers (Gesthuizen 2009), suggesting that this type of dissatisfaction does not trigger a stronger turnover among the higher educated workers. Nevertheless, less education might still be too low in the perception of employers, making them to prefer intermediateeducated applicants, if available, for whom this mismatch is much less likely to occur. This implies that the cascade effect, as described, is still taking place. 
market entry cohorts, ${ }^{2}$ while the size of the group is expected to have declined, these processes might well explain the supposed structurally increasing economic vulnerability of the less-educated compared to the intermediate-educated, in addition to the influence of increasing or decreasing displacement effects.

These two indicators of labor market vulnerability differ for men and women, however. Firstly, women with low levels of education might "choose" parenting and homemaking over competing in the labor market for low-skilled and low-paying jobs (Hakim 1996; Wilson 1990). And secondly, due to sex segregation, the socioeconomic status of female-typed occupations is lower than that of male-typed occupations — even at the same qualification level—and thus the SES scale for female-typed jobs is compressed, compared to the one for male-typed jobs (Bose and Rossi 1983; Tomaskovic-Devey 1993). Due to space restrictions, we are unable to conduct the necessarily separate analyses for men and women and will therefore limit our analysis to men.

We will draw on the repeated cross-sections of the 19742008 US General Social Survey (GSS), which allow for using a cohort design and provide repeated measures of labor market outcomes, verbal skills, and social origin. The GSS data set is uniquely suited for the purpose of our paper because it is one of the few sources that provide measures on cognitive ability (an important indicator for studying cognitive selection processes over entry cohorts), social origin, and labor market outcomes - and this over an highly extended time period, which helps ensure sufficient variation in labor market situations and cohort composition.

We begin our paper with a discussion of the various arguments put forth to explain the higher labor market vulnerability of men with low education. Next, we introduce our data and the definitions of our dependent and independent variables. After that, we discuss our empirical findings, in two steps. First we present descriptive analyses of changes across labor market entry cohorts in displacement, negative cognitive selection, the size of the less-educated group, and negative social selection. Second, we empirically test whether variations across cohorts in these aspects contribute to our understanding of differences in economic vulnerability between less-educated and the intermediate-educated

\footnotetext{
${ }^{2}$ Theoretical expectations might, however, not be empirically confirmed. Therefore, our first goal is to actually study these processes in the United States. The outcomes of these empirical investigations provide a first answer to the question whether these processes might add to the explanation of structurally increasing economic vulnerability of less-educated men in the United States. If there are no structural trends across entry cohorts, but merely fluctuating differences, they might nevertheless contribute to the explanation of idiosyncratic differences in employment opportunities between the less- and intermediateeducated.
}

men. We finish with some conclusions, including a discussion of the merits of our analysis and open questions for future research.

\section{Explaining poorer employment opportunities}

\subsection{Intensified job competition and displacement}

Qualifications have become crucial for attaining highranking and secure positions in modern labor markets (Blau and Duncan 1967; Kerr et al. 1960; Treiman 1970). Technological progress has come along with rising job requirements and an increasing demand for (higher) skilled labor (Autor et al. 2003; Bell 1974; Cappelli 1993; Levy and Murnane 1992). Correspondingly, educational expansion has taken place in many Western societies (Erikson and Jonsson 1996; Shavit and Blossfeld 1993), but the upgrading of jobs has failed, at least temporarily, to keep pace with this increase in educational participation (Berg 1971; Hirsch 1977; Livingstone 1998; Wolbers et al. 2001).

Proponents of human capital theory (Becker 1964), signaling theory (Spence 1974), and job competition/vacancy chains (Sørensen 1977; Sørensen and Kalleberg 1981; Thurow 1975, 1979) have argued that employers tend to regard a job applicant's level of educational attainment as an indicator of that person's (future) productivity and trainability. If we assume the number of vacant jobs to be fixed, this means that the lower an individual's educational degree, the lower their rank in the labor queue. Hence, the larger the relative supply of persons with higher levels of education, the lower the probability for lesseducated workers to be hired. In times of an oversupply of skilled labor, the high-educated cascade downward on the economic ladder, entering jobs previously filled by intermediate-educated workers, who in turn cascade downwards to enter the jobs previously filled by less-educated workers (Thurow 1979: 22). Consequently, better-educated workers increasingly have displaced less-educated workers so that today the latter end up in poorer jobs-or are pushed out of the labor market entirely (e.g., Blossfeld 1985; Boudon 1974; Hirsch 1977; Kalleberg 1996; Thurow 1975; see evidence for Germany: Blossfeld 1990; Pollmann-Schult 2005; Canada: Wanner 2005; Netherlands: Gesthuizen and Wolbers 2010).

According to this line of reasoning, also known as the displacement hypothesis, we would expect to find the following: the larger the high-skill supply-demand ratio within an entry cohort, the higher the risk of unemployment versus employment is for the less-educated, as compared to the risk of unemployment versus employment for the intermediateeducated. For socioeconomic status (SES), if employed, we expect that the larger the high-skill supply-demand ratio is 
in an labor market entry cohort, the smaller the status differential is between the less-educated and the intermediateeducated workers. The reason is that in times of an oversupply of higher educated workers, intermediate-educated workers are pushed into lower status jobs, while bottomeffects for the less-educated leave little room for a further decline in SES (see also Gesthuizen et al. 2011).

\section{2 (Train) ability and conventional signaling}

Goldin and Katz (2008) argue that an oversupply of highskilled workers existed in the United States only until the early 1970s, when Richard B. Freeman wrote his book The Overeducated American (1976). Like proponents of the displacement hypothesis, however, they fail to acknowledge that education groups may change not just in quantitative terms but also in qualitative terms-that is, in terms of their social composition (cf. Solga 2002, 2008). Thus the average (relative) productivity of less-educated workers may have continued to drop across US labor market entry cohorts even after the 1970s, regardless of the labor supply-demand ratio. This may explain why unskilled jobs continued to be filled with skilled workers in the late 1970s and 1980s (Bluestone and Harrison 1988).

The average productivity of education groups is defined not only by educational credentials but also by cognitive skills; hence it may vary across entry cohorts. If the school system became more efficient as a "sorting machine," the skills of less-educated men may on average have decreased from one birth cohort to the next. During educational expansion, the men who remained less educated should have become more negatively selective and homogeneous in terms of their cognitive skills. If cognitive skills of the intermediate-educated group have remained stable across entry cohorts, this would imply an increasing gap in cognitive competences between the less-educated and the intermediate educated group. It remains an empirical question to what extent this process has actually taken place in the United States.

This variation in the absolute and relative cognitive composition of the less-educated group could explain varying differences in labor market risks across labor market entry cohorts, if less-educated men are compared to intermediateeducated men. According to signaling theory, employers tend to judge an individual's potential productivity based on relevant market signals such as educational attainment (Spence 1974; Weiss 1995). Since employers do not know an individual's actual trainability before hiring, they use education as a proxy of productivity or (train)ability. This proxy is applied to all members of an education groupregardless of the actual productivity and cognitive skills of a single applicant. Based on probabilistic belief, all lesseducated workers are seen as having poorer cognitive skills and, thus, a low degree of trainability. This recruitment rule is also known as statistical discrimination (Arrow 1985). The average (cognitive) ability of less-educated workers in a given cohort, as compared to the average cognitive ability of their intermediate-educated counterparts, should therefore influence employers' assessment of their trainability over and above individual ability. We call this mechanism cognitive selection mechanism. In a cross-national study, it has been found that in countries where the average cognitive ability of the group of less-educated workers is lower, educational differences in SES and income are larger (Gesthuizen et al. 2011; Gesthuizen and Scheepers 2010).

We expect that the larger the gap in cognitive ability is in a labor market entry cohort between less-educated and intermediate-educated men, the higher should be the risk of unemployment versus employment for the less-educated, as compared to the risk of unemployment versus employment for the intermediate-educated. Furthermore, under such circumstances we also expect the status differential to become larger between less-educated and intermediateeducated men.

\subsection{Low levels of education as "individual failure"}

Existing research on educational stratification has typically ignored a crucial aspect of educational credentials: Depending on the educational distribution, credentials convey cultural meanings - net (or independent) of cognitive and/or non-cognitive skills, and family background. The growth in the better-educated population has changed our perception of what it means to remain less-educated. Educational expansion has transformed the meaning of "not having completed higher education" into "individual failure" (see Meyer 1977: 62; Parsons 1959: 317). Such a semantic shift is especially likely to occur for cohorts in which the lesseducated group is a social minority. As social psychology research has shown, we are more likely to attach negative attributes to social groups if these groups are relatively small (Jones et al. 1984: 92). Hence an additional mechanism may be involved here, which we call the discrediting mechanism. If the way employers treat less-educated men is influenced by the relative size of this group-regardless of their actual cognitive and/or non-cognitive skills- then smallness itself, bordering on being a social minority deviating from "the norm," should negatively affect the labor market outcomes of less-educated workers (cf. Solga 2008).

Empirically, we should therefore find that the smaller the relative size of the low education group is within a labor market entry cohort, the higher should be the unemployment risks of less-educated men compared to the unemployment risk of intermediate-educated men, and the larger the status differential between both groups.

By using the term discrediting rather than discrimination, we point to a process in which particular negative social 
meanings come to be attached to categories of behavior, in the sense that they mark a deviant status (cf. Fiske 1998; Jones et al. 1984; Goffman 1963). Discrediting thus expresses the labeling of less-educated workers as "deviant" and thereby stereotyping them as having an undesirable character. Whereas statistical discrimination implies a lower rank in the applicant queue, discrediting means a systematic exclusion (or sorting out) from this queue of the lesseducated group in case that they constitute a social minority.

\subsection{Social networks and non-cognitive skills}

In addition to a more negative cognitive composition, as described in Sect. 2.2, educational expansion may also have resulted in a more negative social composition of the lesseducated group over time. Explained through primary and secondary effects of social stratification, class differentials in demonstrated performance and educational decisions are responsible for class differences in educational attainment (Boudon 1974; Breen and Goldthorpe 1997). Conflict theory views educational attainment as a means by which powerful groups defend their status/class privileges, legitimating them via educational differences (cf. Bourdieu 1987; Collins 1979). Both rational choice theory and credential theory suggest that the outflow mobility from the lesseducated group during educational expansion was, and is, not random with respect to social background. This suggests that, while almost everyone finished secondary education, those who were unable to attain higher education relatively often have parents who are either unemployed or employed in unskilled jobs (for Germany see Solga 2002; for the Netherlands see Gesthuizen et al. 2005).

According to Granovetter (1974), Lin (1999), and Tilly (1998), social networks are important factors in the job search and hiring process. Quite frequently, it is through social networks that applicants learn about job openings, receive second-hand accounts of job requirements, or-if the network includes employed persons-improve their reputation with employers. Without such a network, or with a network that mainly includes other less-educated persons employed in unskilled jobs (if employed at all), a less-educated person's job search is far more often directed towards lowskilled jobs than that of a better-educated person. ${ }^{3}$ We would

\footnotetext{
${ }^{3}$ The social network argument can be read as if, due to their social networks, people do not get information on jobs outside of their levels. This would imply that higher skilled people would not be informed about lower level jobs, resulting in the higher educated not filling these positions, even though competition intensifies. To some extent this might indeed be the case, but there are several arguments against this perspective. First, some high-educated men already work in intermediate-level jobs, and some intermediate-educated men already work in low skilled jobs. Second, we are studying entry level jobs in the United States, and in the US particularly, low skilled entry level jobs are often available to both less- and intermediate-educated entrants.
}

therefore expect that the more negatively selective the social composition of the less-educated group is in a given labor market entry cohort, the higher the risk of unemployment will be for less-educated men, as compared to intermediate educated men, and the larger should be socioeconomic status differences between employed less- and intermediateeducated individuals. We call this mechanism impoverished network resources.

A second line of reasoning suggests another explanation connected to changes in social composition. Conventional signaling literature considers education mainly in terms of abilities. But educational degrees also signal non-cognitive skills (cf. Cappelli 1995; Heckman and Rubinstein 2001). Cappelli (1995: 109-110) argues that employers' most important consideration in hiring "was not so much about lack of vocational skills, but about deficits in more basic skills," which include "solid grounding in reading, writing, arithmetic, and communication skills" as well as work attitudes and behavior and motivational orientation. Employers see good habitual work behavior as particularly important for adapting "successfully to the work environment" (Cappelli 1995: 110) and "facilitating efficient individual and organizational functioning" (Farkas 2003: 541). Heckman and Rubinstein (2001) support this view, arguing that educational credentials are "a mixed signal" that "conveys information about both cognitive and non-cognitive skills" (Heckman and Rubinstein 2001: 145; cf. also Rosenbaum and Binder 1997). Echoing Bowles and Gintis (1976; Bowles et al. 2001), they claim that employers reward the same noncognitive skills as school teachers. Thus choice of schoolrevealed by its outcome, that is, an individual's educational attainment/credential—signals trainability in terms of cognitive skills, motivation to learn, and non-cognitive skills (personality and learning habits). There are good reasons to believe that this is especially true of less-educated workers, because if verbal skills are low, employers will take behavioral characteristics as important determinants of trainability (see Farkas 2003: 556).

Given the increase in educational participation during the last 50 years, it is reasonable to assume individuals with positive work behavior characteristics to have "left" the low education group. As a consequence, the average non-cognitive skills of those who have "remained" in the low education group may have decreased. We call this mechanism negative non-cognitive selection. There is a large body of research indicating that family background-irrespective of a child's cognitive abilities - is a good predictor of a child's non-cognitive skills (see Farkas 2003), either because employers directly use family background as a cultural signal conveying information about the behavioral models that applicants have adopted from their parents, or because family background, for the same reason, can be taken as a proxy variable of a child's non-cognitive skills (cf. Bowles et al. 2001: 1171; Cappelli 1995: 116). 
Both mechanisms-impoverished networks and negative non-cognitive selection-should therefore contribute to higher risks of unemployment and lower job placements in terms of SES for less-educated men compared to intermediate-educated men in cohorts in which the gap in parental SES between the less- and intermediate-educated is larger. Because measurements of non-cognitive skills are not available in the GSS, we are unable to distinguish between impoverished network resources and negative non-cognitive selection in this paper.

\section{Data, measurements, and methods}

\subsection{Data: General Social Survey, 1974-2008}

We use the 1974-2008 samples of the US General Social Survey (GSS), in which data on both verbal skills and family background are available. As an annually conducted survey (biannually from 1994), the GSS offers a unique opportunity for using cohort analysis to simultaneously investigate whether there is a trend towards an increasing selectivity of the less-educated group, and, if so, which of the various mechanisms are most relevant in this context.

Each of the GSS samples is representative of the noninstitutionalized English-speaking US population (18 years of age and older). To ensure that less and intermediateeducated men compete in the labor market (at the same time), our analysis only involves respondents at age of labor market entry (in the age range between 18 and 30 years). In each GSS wave, the vocabulary test-our measurement of cognitive skills-was conducted only for a random subsample, however. Since taking account of cognitive skills is essential for our analysis, the final GSS data set we used included 2.339 male respondents for studying unemployment risks, and 2.139 male respondents for studying the socioeconomic status of the employed 18-30 year old male US working force. ${ }^{4}$

\subsection{Dependent variables}

Our dependent variables are (a) the respondents' risk of being unemployed (unemployed, laid off) compared to being

\footnotetext{
${ }^{4}$ The total GSS stacked dataset 1974-2008, contains 49.926 respondents. After selecting the 18 to 30 year old participants, 11.764 respondents remain. 7.198 of those are either employed (fulltime or part-time) or unemployed/laid off. After making the selection of valid scores on the verbal ability test, 3.732 respondents remain, and selecting men only and deleting list-wise missing values, decreases the dataset further to 2.339 respondents. A final selection of working males leads to an analytical data set of 2.139 respondents. There are no specific reasons to assume that after these selections, problems occur regarding the representativeness of our sample. We assume that our dataset is representative for 18 to 30 working and unemployed males, in the respective year of measurement.
}

in regular employment (fulltime or part-time) and (b) their socio-economic status (SES) at the time of the interview. We use the employment status and SES at entry into the labor market in order to control for occupational experience (which is not available in GSS) and to ensure that we look at men who were competing with each other at the time of interview. For SES, the International Standard Classification of Occupation (ISCO) of 1968 for the earlier waves, and of 1988 for the later waves, have been transformed into the International Socio-Economic Index (ISEI) developed by Ganzeboom et al. (1992), using a minimum value of 10 and a maximum value of 90 .

\subsection{Independent variables at the individual level}

Respondents' educational attainment is categorized as less than high school (low level of education), high school or junior college (intermediate level of education), and bachelor or master degree (higher level of education). Respondents' verbal skills - our indicator of cognitive skills-were measured by the GSS vocabulary knowledge test (Miner 1957; Thorndike 1942). Correlations between vocabulary test scores and general measures of ability have proved to be high (Alwin and McCammon 1999; Miner 1957). The test consists of ten words, for which the respondent has to choose the correct synonym out of five alternatives. The verbal test scale ranges from 0 to 10. Family background is indicated by parental socioeconomic status (SES). As for respondent SES, we transformed parents' ISCO codes into the ISEI scale, using the highest score in the case of two parents. To facilitate the interpretation of the models' coefficients, this variable was linearly transformed to having a range of 0 to 1 (minus 10 and divided by 78). The coefficients thus depict the change in the dependent variables, if parental SES would changes from its minimum to its maximum score.

As the year of labor market entry is not directly available in GSS, we estimated it for each respondent. First, we selected 18- to 30-year-old respondents. After that, we used the variable "highest year of school completed" to estimate the age at which the respondent left school. The highest figure for years of school completed was 20, and the maximum age of leaving school was 24 years. Finally, by adding the school-leaving age to respondents' year of birth, we estimated the year of labor market entry. To ensure that the number of respondents in each entry year was sufficient for us to aggregate our cohort-replacement variables and break them down by educational level, we selected the entry years ranging from 1965 to 1999. For estimating our general trend models (see below for a precise description of our method and the steps taken therein), we recoded this variable into four entry cohorts: 1965-1975, 1975-1984, 1985-1994, and 1995-1999.

As control variables, we included respondents' age (centered around its mean), the unemployment rate in the year 
of the interview, marital status, number of children, ethnicity (white, black, other), and region (Southern or otherwise).

\subsection{Independent variables at the group level}

The repeated nature of the GSS enables us to perform cohort analyses that empirically separate cohort effects from age and period effects (Mason et al. 1973; Glenn 1977). Thus, labor market entry years can be replaced with theoretically relevant aggregates while, at the same time, age and time of interview (period) can be controlled for (cf. Menard 1991). Time of interview is replaced by the unemployment rate. In this way, we take into account cyclical influences on educational differentials in employment opportunities and provide a comprehensive solution for the perfect multi-collinearity when age, period, and cohort are included into the model simultaneously (the so-called APC-problem).

Our entry cohort replacements indicate the different social mechanisms explaining differences in labor market disadvantages of the low education group as compared to the intermediate-educated men, conditional upon specific characteristics of the labor market entry cohort. They are all aggregated from the GSS. The high-skill supply-demand ratio (indicator of displacement) is calculated as the percentage of high-skilled individuals in a given entry year divided by the same year's percentage of high-skill jobs (SES higher than 60). Yet, this indicator cannot account for the possibility that some positions remain unfilled, for example, because of a shortage of individuals qualified for that position. Negative cognitive selection (ability signaling) is indicated by entry year-specific differences in the average vocabulary score between the less- and the intermediate-educated men. The discrediting hypothesis is tested by including the relative cohort size of the less-educated group for each entry year. For investigating impoverished network resources and/or negative non-cognitive selection (negative social selection), we use the difference in entry year-specific parental SES averages between the less- and intermediate-educated group. For all variables we have calculated moving averages over 5 years, to take account of large jumps between them. In Table 4 in the Appendix, the correlations between these cohort replacement variables are presented. They are mostly weak, indicating that multi-collinearity does not play a role in our analyses, when including them simultaneously.

In Table 1, descriptive information (minimum, maximum, and mean, and in case of interval variables also its standard deviation) is presented for all variables. Regarding our dependent variables, we see that on average 8 percent of the sample was unemployed, while the average SES of the working population of 18 to 30 year old men was somewhat higher than 41.

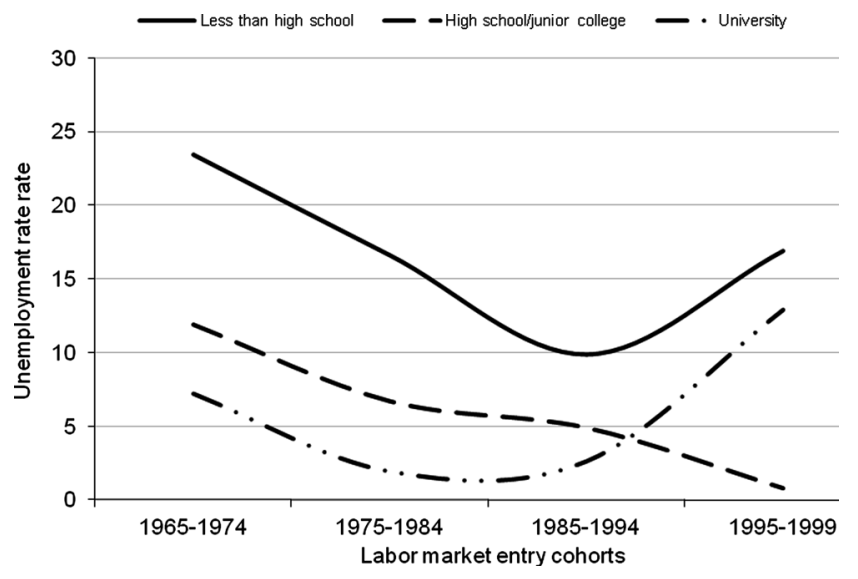

Fig. 1 Educational differences in men's employment rates across labor market entry cohorts (10-year-averages, weighted figures). Source: Authors' calculations; General Social Survey 1974-2008

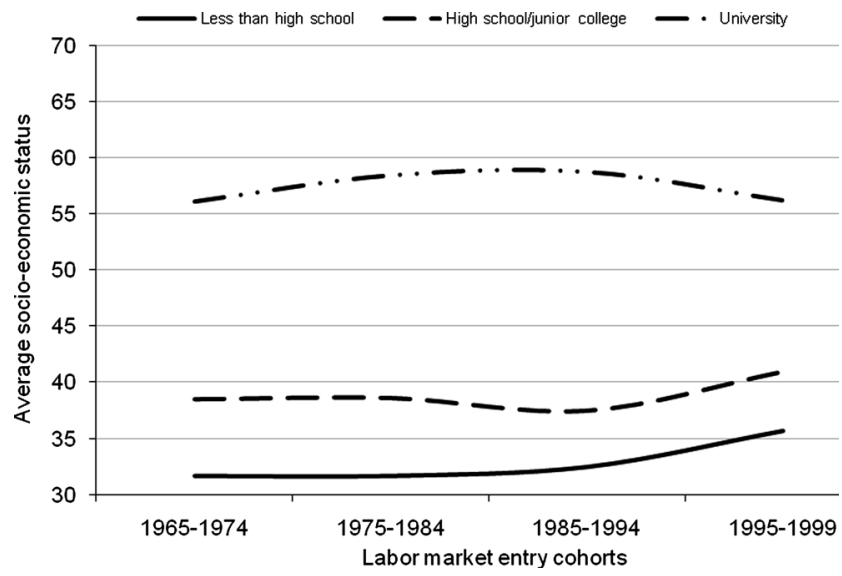

Fig. 2 Educational differences in men's SES at the time of the interview across labor market entry cohorts (10-year-averages, weighted figures). Source: Authors' calculations; General Social Survey $1974-2008$

\subsection{Methods}

We take several steps in presenting our findings and in empirically testing our hypotheses. First, we present descriptive results on educational differences in unemployment risks (Fig. 1) and SES (Fig. 2) across labor market entry cohorts.

Second, we present descriptive findings of changes across labor market entry cohorts, broken down by educational attainment, regarding the high-skill supply-demand ratio to indicate displacement and the percentage of lesseducated men to indicate discrediting (both Fig. 3), the average verbal skills to indicate negative cognitive selection (Fig. 4), and average parental SES to indicate negative social selection (Fig. 5). These descriptive findings provide a first picture of which processes might be at work to explain structurally decreasing labor market outcomes for the lesseducated as compared to their intermediate-educated coun- 
Table 1 Descriptive statistics

\begin{tabular}{|c|c|c|c|c|}
\hline & Minimum & Maximum & Mean & Std. deviation \\
\hline \multicolumn{5}{|l|}{ Dependent variables } \\
\hline Unemployment $^{\mathrm{a}}$ & 0 & 1 & 0.08 & \\
\hline Socioeconomic status ${ }^{b}$ & 16 & 88 & 41.37 & 14.69 \\
\hline \multicolumn{5}{|l|}{ Independent variables $^{\mathrm{c}}$} \\
\hline Less-educated & 0 & 1 & 0.15 & \\
\hline Intermediate-educated & 0 & 1 & 0.68 & \\
\hline High-educated & 0 & 1 & 0.17 & \\
\hline Verbal skills & 0 & 10 & 5.49 & 1.95 \\
\hline Parental SES & 0 & 1 & 0.44 & \\
\hline Parental SES missing & 0 & 1 & 0.18 & \\
\hline Entry cohort 1965-1974 & 0 & 1 & 0.27 & \\
\hline Entry cohort $1975-1984$ & 0 & 1 & 0.35 & \\
\hline Entry cohort 1985-1994 & 0 & 1 & 0.29 & \\
\hline Entry cohort 1995-1999 & 0 & 1 & 0.09 & \\
\hline Age (centered) & -7 & 5 & -0.24 & 3.31 \\
\hline Married & 0 & 1 & 0.37 & \\
\hline Widowed & 0 & 1 & 0.00 & \\
\hline Divorced & 0 & 1 & 0.05 & \\
\hline Single & 0 & 1 & 0.58 & \\
\hline Number of children & 0 & 6 & 0.56 & 0.94 \\
\hline White & 0 & 1 & 0.80 & \\
\hline Black & 0 & 1 & 0.14 & \\
\hline Other race & 0 & 1 & 0.06 & \\
\hline South & 0 & 1 & 0.16 & \\
\hline Other region & 0 & 1 & 0.84 & \\
\hline Unemployment rate & 4 & 9.70 & 6.26 & 1.47 \\
\hline Displacement & 0.84 & 2.08 & 1.29 & 0.24 \\
\hline Negative cognitive selection & 0.46 & 1.87 & 1.12 & 0.35 \\
\hline Discrediting & 0.02 & 0.32 & 0.16 & 0.06 \\
\hline Negative social selection & 2.35 & 12.56 & 5.57 & 2.51 \\
\hline
\end{tabular}

${ }^{a}$ Valid $N=2339$

${ }^{\mathrm{b}}$ Valid $N=2139$

${ }^{\mathrm{c}}$ The descriptive of the independent variables are based on the number of observations of unemployment $(N=2339)$.

There are hardly any differences in the distributions when they are based on the individuals with a valid score on SES $(N=2139$; results available on request)

terparts, and which processes might explain idiosyncratic differences (see also note 2 ).

In a third step, we estimate multivariate logistic regression models for unemployment risk and OLS regressions for SES (Table 2) in which interactions between the educational groups and labor market entry cohorts are included. These interactions show to what extent differences in labor market outcomes between educational groups are smaller or larger in the four entry cohorts that we distinguished. They answer the question whether there are structural increases, or merely idiosyncratic differences in labor market risks, if we compare the less-educated with the intermediate- (or high-) educated across the four entry cohorts.

In a final and fourth step, we replace the four labor market entry cohorts with the labor market entry cohort replacement variables (displacement, negative cognitive selection, discrediting, and negative social selection), as de- scribed in Sect. 3.4, and interact them with the educational groups (Table 3). Should we, for instance, find a significant negative main effect of being intermediate-educated and a significant negative interaction for being intermediateeducated $*$ negative social selection (the less-educated being the reference group), this would mean that the unemployment risk of the intermediate-educated, as compared to the unemployment risk of the less-educated, is on average smaller (main effect), and would be even smaller in entry cohorts where the gap in average parental SES between both educational groups is larger. Put the other way around: The relative unemployment risk for the less-educated is larger in labor market entry cohorts where negative social selection is stronger. If negative social selection structurally increased over labor market entry years, this finding would provide an explanation for structurally increasing labor market risks. Does it merely fluctuate, it can at best be an explanation 
Table 2 Educational differentials in labor market outcomes, men

\begin{tabular}{|c|c|c|c|c|}
\hline & \multicolumn{2}{|c|}{$\begin{array}{l}\text { Unemployment vs. employment } \\
\text { Logistic Regression } \\
\text { (logit coefficients) }\end{array}$} & \multicolumn{2}{|c|}{$\begin{array}{l}\text { SES } \\
\text { OLS regression } \\
\text { (unstandardized coefficients) }\end{array}$} \\
\hline & Model 1 & Model 2 & Model 1 & Model 2 \\
\hline \multicolumn{5}{|c|}{ Respondent's educational attainment (low = ref.) } \\
\hline Intermediate & $-0.73^{* *}$ & $-0.61^{* *}$ & $4.32^{* *}$ & $4.61^{* *}$ \\
\hline High & $-0.65^{*}$ & $-0.76^{* *}$ & $19.87^{* *}$ & $18.78^{* *}$ \\
\hline Respondent's verbal skills & 0.01 & 0.02 & $1.05^{* *}$ & $1.05^{* *}$ \\
\hline Respondent's parental SES ${ }^{\mathrm{a}}$ & $-1.36^{* *}$ & $-1.34^{* *}$ & $6.84^{* *}$ & $6.83^{* *}$ \\
\hline \multicolumn{5}{|l|}{ Labor market entry cohort 1965-1974 (ref) } \\
\hline Labor market entry cohort $1975-1984$ & $-0.75^{* *}$ & $-0.62 \sim$ & 0.53 & 0.26 \\
\hline Labor market entry cohort 1985-1994 & $-1.04^{* *}$ & $-1.15^{*}$ & -0.26 & -0.21 \\
\hline Labor market entry cohort 1995-1999 & $-1.01^{* *}$ & -0.58 & 1.12 & 2.54 \\
\hline Age & $-0.07^{* *}$ & $-0.72^{*}$ & $0.45^{* *}$ & $0.44^{* *}$ \\
\hline Unemployment rate & $0.16^{* *}$ & $0.16^{* *}$ & $-0.48^{*}$ & $-0.50^{*}$ \\
\hline \multicolumn{5}{|l|}{ Interaction: Education ${ }^{*}$ cohort } \\
\hline 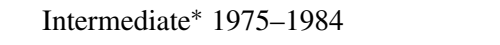 & & -0.13 & & 0.05 \\
\hline 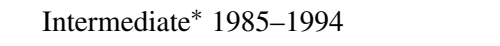 & & 0.15 & & -0.81 \\
\hline 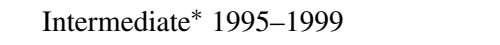 & & $-2.48^{*}$ & & -0.90 \\
\hline High* 1975-1984 & & -0.94 & & 1.73 \\
\hline High* 1985-1994 & & 0.02 & & 2.74 \\
\hline High* 1995-1999 & & 1.21 & & -3.35 \\
\hline Intercept & $-2.70^{* *}$ & $-2.80^{* *}$ & $30.09^{* *}$ & $30.33^{* *}$ \\
\hline Number of observations & 2339 & 2339 & 2139 & 2139 \\
\hline Degrees of freedom & 17 & 23 & 17 & 23 \\
\hline Explained variance ${ }^{\mathrm{b}}$ & $12.8 \%$ & $14.9 \%$ & $32.5 \%$ & $32.8 \%$ \\
\hline
\end{tabular}

Controlled for: Family status, number of children, ethnicity, Southern region/others (full table is available on request by the authors)

${ }^{a}$ Category for missing cases is included in the model

${ }^{\mathrm{b}}$ For employment chances the Nagelkerke $R^{2}$ is documented

Level of significance: $\sim p<0.10 ;{ }^{*} p<0.05 ;{ }^{* *} p<0.01$

Source: Authors' calculations; General Social Survey 1974-2008

for idiosyncratic increases in labor market risks for the lesseducated.

\section{Results}

4.1 Descriptive findings: educational differences in labor market outcomes

Figures 1 and 2 and Table 2 display the labor market outcomes of our educational groups across US labor market entry cohorts. Figure 1 shows that in all cohorts, lesseducated men faced the highest risk of being unemployed. The unemployment rate dropped from 24 percent in 19651974 cohort to 10 percent in the 1985-1994 cohort, to rise again to 17 percent in the youngest entry cohort. For the highest-educated men, there is a similar pattern. For the intermediate-educated, we see a constant drop in the unemployment rate, also for the youngest cohort. This implies that particularly from the 1985-1994 cohort to the youngest cohort, relative unemployment risks increased sharply for less-educated 18 to 30 year old male Americans. Table 2 shows the significance of this latter finding. Model 1 shows that across cohorts, on average the risk of unemployment decreased. Yet, the significant and negative interaction of -2.48 for 'intermediate-educated $* 1995-1999$ ' shows that the gap in the unemployment risk between the less- and intermediate-educated group became significantly larger, at the expense of the less-educated.

For status attainment of less-educated men, we see that their average SES score is lowest in all cohorts, but that the large SES difference between the less- and the intermediate- 
Table 3 Educational differentials in labor market outcomes, including cohort replacements, men

\begin{tabular}{|c|c|c|c|c|}
\hline & \multicolumn{2}{|c|}{$\begin{array}{l}\text { Unemployment vs. employment } \\
\text { Logistic Regression } \\
\text { (logit coefficients) }\end{array}$} & \multicolumn{2}{|c|}{$\begin{array}{l}\text { SES } \\
\text { OLS regression } \\
\text { (unstandardized coefficients) }\end{array}$} \\
\hline & Model 1 & Model 2 & Model 1 & Model 2 \\
\hline \multicolumn{5}{|l|}{ Education (Less-educated = ref.) } \\
\hline Intermediate & $-0.66^{* *}$ & -0.85 & $4.43^{* *}$ & -0.11 \\
\hline High & $-0.61^{* *}$ & $-8.22^{* *}$ & $20.06^{* *}$ & $28.71^{* *}$ \\
\hline Respondent's verbal skills & -0.00 & -0.01 & $1.07^{* *}$ & $1.08^{* *}$ \\
\hline Respondent's parental SES & $-1.35^{* *}$ & $-1.23^{*}$ & $6.76^{* *}$ & $6.68^{* *}$ \\
\hline \multicolumn{5}{|l|}{ Cohort replacement variables } \\
\hline Displacement & $0.65^{*}$ & -0.24 & $-2.31 \sim$ & -0.09 \\
\hline Negative cognitive selection & $0.64^{*}$ & 0.56 & -0.17 & -1.30 \\
\hline Discrediting & $4.27^{* *}$ & 1.67 & 5.85 & -4.24 \\
\hline Negative social selection & 0.00 & 0.10 & 0.12 & -0.10 \\
\hline \multicolumn{5}{|l|}{ Education* Cohort replacement } \\
\hline Intermediate* displacement & & 0.49 & & -1.19 \\
\hline High* displacement & & $4.20^{*}$ & & -7.42 \\
\hline Intermediate* negative cognitive selection & & -0.15 & & 1.31 \\
\hline High* negative cognitive selection & & -0.46 & & 1.90 \\
\hline Intermediate* discrediting & & 3.75 & & 18.75 \\
\hline High* discrediting & & 9.94 & & -16.24 \\
\hline Intermediate* negative social selection & & $-0.18^{*}$ & & 0.26 \\
\hline High* negative social selection & & 0.07 & & 0.17 \\
\hline Intercept & $-5.63^{* *}$ & $-4.55^{* *}$ & $31.62^{* *}$ & $33.35^{* *}$ \\
\hline Number of observations & 2339 & 2339 & 2139 & 2139 \\
\hline Degrees of freedom & 18 & 26 & 18 & 26 \\
\hline Explained variance (Nagelkerke $R^{2}$ ) & $12.6 \%$ & $15.0 \%$ & $32.1 \%$ & $32.2 \%$ \\
\hline
\end{tabular}

Controlled for the same control variables as in Table 2, plus age and annual unemployment rate

Level of significance: $\sim p<0.10 ;{ }^{*} p<0.05 ;{ }^{* *} p<0.01$

Source: Authors' calculations; General Social Survey 1974-2008

(and high-) educated men is rather stable over time (Fig. 2). Descriptively, educational differences in SES seem to have decreased a bit across entry cohorts, but the multivariate models for SES in Table 2 (Model 2) show insignificant main effects of entry cohorts, as well as for its interaction with education, which means that the educational differences in SES are stable across entry cohorts.

Additionally, Table 1 shows that, as expected, males with more verbal skills enter jobs with a higher SES (but do not have a lower unemployment risk). Furthermore, having parents with a higher level of socioeconomic status prevents young males from unemployment and supports a higher status job at entry into the labor market. More experience (indicated by a higher age) is associated with lower unemployment risks and a higher entry status. Finally, in times of higher levels of aggregate unemployment, individuals' risks of unemployment increase, while the status of entry jobs decrease. $^{5}$

\footnotetext{
${ }^{5}$ Note that we interpret the effects of these independent individual level variables under control of all other variables in the model. For parental SES, for instance, this means that its impact is independent of educational attainment and verbal ability of the respondent (their child). Social stratification literature shows that there is a causal order for those characteristics. Yet it is beyond the scope of this article to incorporate this causal approach. The reason why we adopt parental SES as an individual level variable, and estimate net effects of it by controlling for education and verbal ability, is that this comes close to an indicator of individual network resources. We need to take account for this to be able to address the social network composition of the less-educated group, in terms of aggregated parental SES.
} 


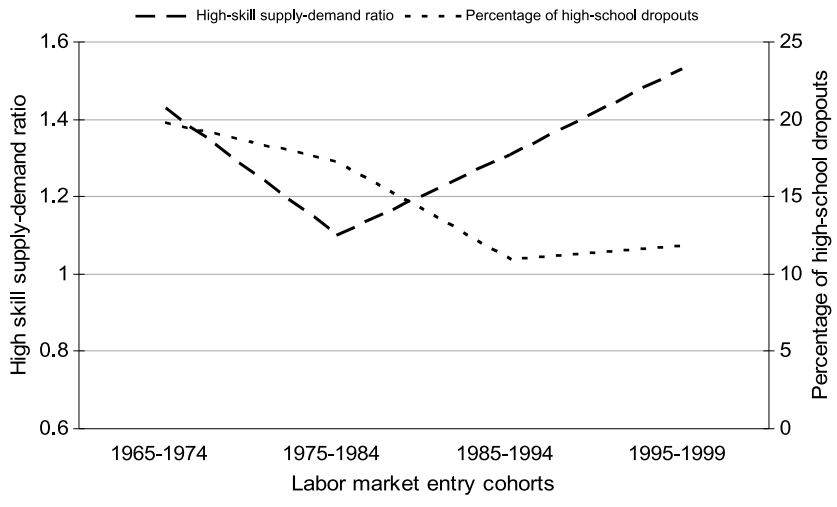

Fig. 3 High-skill supply-demand ratio and relative size of less-educated men across labor market entry cohorts (10-year-averages, weighted figures). Source: Authors' calculations; General Social Survey 1974-2008

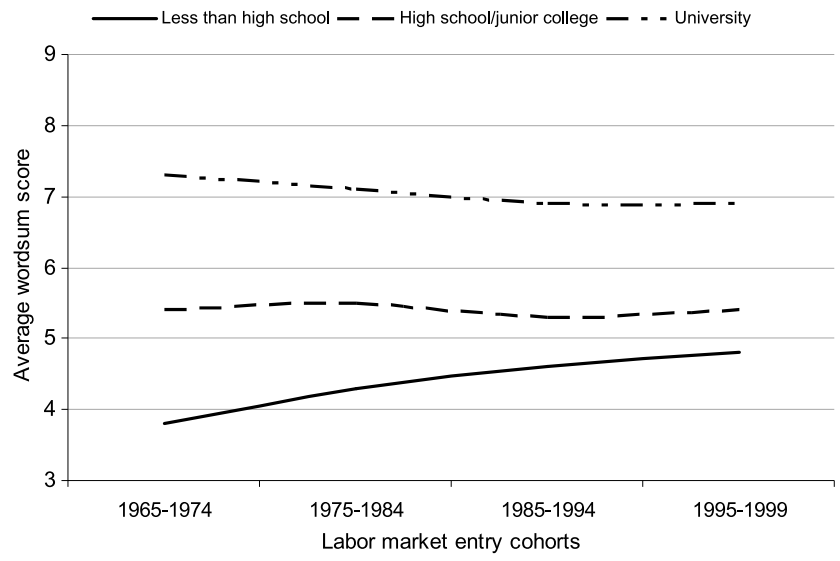

Fig. 4 Average verbal skills of education groups across labor market entry cohorts (10-year-averages, weighted figures). Source: Authors' calculations; General Social Survey 1974-2008

\subsection{Descriptive findings: explanations for educational differences}

The question is which processes can be considered serious candidates for explaining structurally or temporarily decreasing labor market opportunities for the less-educated. Figures 3, 4 and 5 show the changes in the variables indicating displacement, discrediting, negative cognitive selection, and negative social selection across labor market entry cohorts. First, Fig. 3 reveals that even though the high-skill supply-demand ratio was lowest for the 1975-1984 entry cohort, it was substantially higher for the 1985-1994 entry cohort, and still higher for the youngest cohort. Increased displacement might thus be a structural force resulting in increased relative labor market disadvantages of the lesseducated. The same holds for discrediting, as Fig. 3 clearly shows that the percentage of less-educated people dropped across the cohorts (the youngest cohort being an exception),

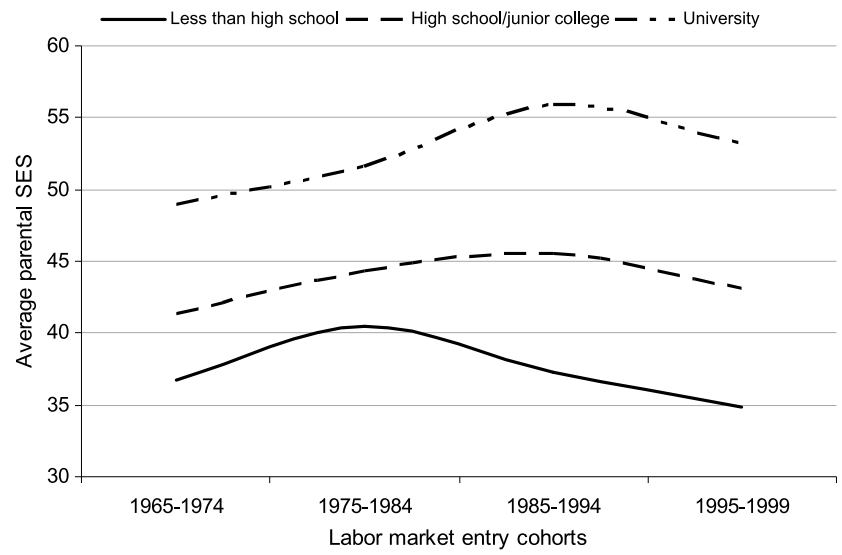

Fig. 5 Average parental SES of educational groups across labor market entry cohorts (10-year-averages, weighted figures). Source: Authors' calculations; General Social Survey 1974-2008

suggesting that the cultural meaning of being less-educated deteriorated and became a signal of personal failure.

Figure 4 displays that in all entry cohorts, less-educated men in the United States possess on average a lower level of verbal skills than men with intermediate and higher education. Yet across cohorts, the average level of verbal skills increased for the less educated, while for the intermediateeducated it remained stable, resulting in a smaller educational gap in verbal skills. This is in contradiction with our expectation. We come back to this point in our discussion. In our data negative cognitive selection did not occur, and as such it cannot function as an explanation for structurally increasing relative labor market risks for the less-educated.

The finding is different when considering negative social selection (Fig. 5). The average parental SES of men with low education was highest in the 1975-1984 cohort (40.5) and lowest in the 1995-1999 cohort (34.8), whereas that of the groups with intermediate and higher education was higher in the two younger entry cohorts. Thus, relative differences between the less- and the intermediate-educated in family background have risen across entry cohorts. In relative perspective, this indicates that, as expected, the social composition of the less-educated group has become more negatively selective in the United States, and might thus explain increasing relative labor market risks for the less-educated.

\subsection{Explanations for educational differences: hypotheses testing}

In our final step, we test in a multivariate framework to what extent these four processes contribute to the explanation of the difference in labor market risks between the lesseducated and the intermediate-educated. Therefore, we now replace year of labor market entry by the theoretically relevant cohort characteristics that indicate the different mechanisms. The results are displayed in Table 3. Models 1 dis- 
plays the average effects of displacement, negative cognitive selection, discrediting, and negative social selection. In Models 2, interactions with educational groups are added. These interaction effects indicate the extent to which educational differences in labor market outcomes vary depending on the characteristics of a respondent's entry cohort.

Model 1 for unemployment versus regular employment shows that the average risk of unemployment versus regular employment is higher entry cohorts where displacement is larger, negative cognitive selection is stronger, and the risk of discrediting is higher. For negative social selection we do not find a significant average effect. The question is which processes particularly affect the less-educated. Model 2 for unemployment versus regular employment shows two interesting results. In the first place, a high high-skill supplydemand ratio does not increase the relative unemployment risk of the less-educated (versus the intermediate-educated). To the contrary, the high-educated themselves face the negative consequences: The higher this supply-demand ratio, the smaller becomes the gap in the employment risks between them and the less-educated (the main effect is 8.22, and the interaction effect 4.20 ). The estimated probability of unemployment for the less-educated, when displacement has its lowest value (0.84) is 0.035 , meaning that under such circumstances the estimated unemployment rate is 3.5 percent. ${ }^{6}$ At the highest value of displacement, the estimated unemployment rate drops to 2.6 percent. When changing displacement from its minimum to its maximum, for the high-educated, the estimated unemployment rate increases from almost zero, to 3.5 percent. Thus, in the United States under conditions of stronger competition, the less-educated are not disproportionally pushed into unemployment, but the high-educated are. This is contrary to our expectations.

Second, the significant negative interaction effect of intermediate-educated $*$ negative social selection of -0.18 , shows that the relatively lower unemployment risk for the intermediate-educated, as compared to the less-educated, becomes even lower when negative social selection of the less-educated is more pronounced. Thus, under conditions of more negative social selection, the less-educated are pushed into unemployment more strongly. By varying between the minimum and maximum level of negative social selection, the estimated unemployment rate for the intermediate-educated drops a bit from 0.8 percent to 0.2 percent, while for the less-educated it increases from 2.6 percent to 4.9 percent. This confirms our expectations.

\footnotetext{
${ }^{6} \mathrm{We}$ calculated this estimated probability by filling in the regression equation (Model 2). For all interval variables (including the cohort replacement variables) we used the average score, and for the categorical variables we used the reference categories (Married, white, other region than South). Subsequently we varied on educational attainment and the value of the cohort replacement variable of interest, in this case displacement. Finally, the estimated logit has been transformed into a probability, by EXP(estimated logit)/(1 + EXP(estimated logit).
}

For discrediting and negative cognitive selection we do not find significant interactions with educational attainment, which means that these processes do not contribute to relative differences in unemployment risks between educational groups. Our expectations regarding these processes therefore do not hold empirically.

For SES, we can be very brief. For the average effects of our cohort replacement variables, we only find one marginally significant negative effect of displacement, meaning that the higher the high-skill supply-demand ratio (the more oversupply), the lower the average SES at labor market entry. Yet, there is no single significant interaction between educational attainment and our cohort replacement variables. This means that the four characteristics of the entry cohorts do not affect the differences in SES between the less- and intermediate-educated when they enter the labor market.

\section{Conclusion and discussion}

The aim of the paper was to offer a more comprehensive explanation of the limited labor market opportunities of lesseducated men. In addition to displacement and job competition, we have expanded the explanation by several other mechanisms: processes of negative cognitive, non-cognitive, and/or social selection, as well as discrediting processes.

Our analyses of US data reveal several interesting findings. First, our comparison of unemployment risks and socioeconomic status across educational groups and labor market entry cohorts shows that only for unemployment risks, the relative position of the less-educated, as compared to the intermediate-educated, deteriorated. This particularly was the case for the youngest entry cohort compared to earlier cohorts. For SES the disadvantageous position of the less-educated did neither improve nor worsen.

Second, not all processes proved to be relevant candidates for explaining the relative increase of unemployment risks of the less-educated. Educational expansion has not resulted in a more negative cognitive selection within the group of lesseducated men. On the contrary, university graduates suffered the most from declining average scores in vocabulary tests. Yet, as indicated by the increasing differences in average parental SES between the three education groups, the social network resources and/or non-cognitive skills of the less-educated group have diminished across cohorts. Furthermore, across cohorts the oversupply of high-educated workers increased, indicating that displacement might well play a role in explaining an increase in the unemployment risk of the less-educated. The same might hold for the discrediting mechanism: The size of the group of less-educated men in the US strongly declined, thus possibly depicting that the group has become increasingly socially deviant. 
Third, our multivariate regression analyses, in which we incorporated cohort replacement variables to empirically test the extent to which the processes might explain differences in labor market vulnerability between the less- and intermediate educated, showed that a higher relative risk of unemployment for the less educated was only related to the extent of negative social selection in an entry cohort. As negative social selection increased, occurring particularly in the youngest entry cohorts, the risks of unemployment increased accordingly. Thus, negative social selection provides a structural, new explanation for the increased unemployment risks of 18 to 30 year old less-educated men in the United States. Contrary to our expectations, an oversupply of high-educated men does not increase unemployment risks for the less-educated. It does so, however, for the high-educated themselves. This suggests that in the United States, displacement does not take place through cascading downwards of higher-educated groups on the occupational ladder, eventually pushing the less-educated from the labor market. An oversupply of high-educated men is disadvantageous particularly for the higher educated, as they are unemployed more often in times of oversupply. This might, however, also indicate that under such circumstances they search longer for a job that matches their capability, and do not accept the first-lower status-job that comes along.

In sum, the increased labor market vulnerability of lesseducated men in terms of unemployment risks (for SES, educational differences have remained stable) is not about intensified job competition. It is about disadvantageous social resources in terms of impoverished social networks and/or poor or poorer non-cognitive skills.

Several open research questions remain. First, what would be the story for changes in less-educated women's labor market outcomes? Second, how general are our US labor market findings? For the Netherlands, for instance, it has been found that negative cognitive selection has taken place (Gesthuizen and Kraaykamp 2002). However, this finding has not yet been linked to changes in the labor market vulnerability of Dutch workers with low education. For the US we did not find an increasing negative selection on cognitive abilities. Is it really the case that US less-educated men became cognitively more able, for instance by a wellperforming educational system? And what about decreasing positive cognitive selection among the high-educated? Our analyses suggest that nowadays cognitively less able persons are more likely to enroll in higher education than previously. Yet, our indicator of cognitive ability-verbal ability - might not be optimal for our purposes, because it is measured after finishing school, and pertains to only a small fraction of what cognitive ability, or intelligence, encompasses. More research is needed to further scrutinize the impact of increasing negative cognitive selection, and decreasing positive selection, for that matter. Third, concerning negative social selection, what is the impact of social networks and non-cognitive skills? We were unable to empirically separate these theoretically plausible explanations. Fourth, we were unable to account for educational differences in geographical mobility, which interfere with occupational choices.

Despite these shortcomings, the analysis in this paper does have some merits. It broadens our view of what education, or belonging to an education group, could mean in modern societies. Our findings challenge commonly used strategies to investigate and solve labor market problems of the less educated. Displacement would suggest that in a situation of supply shortage of skilled labor, less-educated workers would have better job opportunities. Thus job creation (alone) would be a more or less sufficient solution. However, our results have shown that this is unlikely to be true. Employers may still not be willing to hire less-educated workers due to a (presumed) lack of non-cognitive skills. And less-educated workers may furthermore lack sufficient social network resources for their job search.

\section{Executive summaries}

The fact that less-educated men are exposed to higher labor market risks is commonly explained by what is known as the displacement hypothesis. If there is an oversupply of higher educated workers, through a cascade effect the less-educated are eventually pushed into the most elementary jobs in the secondary labor market, or even into unemployment. The main weakness of the displacement argument is that it tends to disregard possible shifts that may occur as a result of changes in the educational system or educational expansion across labor market entry cohorts. Examples of such changes include processes of negative selection regarding the cognitive, non-cognitive/social composition of groups of less-educated individuals, as well as changes in the cultural meaning attached to specific (low) educational credentials. We argue that explanations of (long-term) changes in the employment opportunities of less-educated individuals also need to consider these shifts.

In this article, we investigated whether, and if so how, the verbal skills of less-educated men, as well as the social composition of this education group, varied across labor market entry cohorts, using the repeated cross-sections of the US General Social Survey of 1974 to 2008. Moreover, we looked at the extent to which these variations in cognitive and social composition, measured by verbal ability and parental socioeconomic status respectively, and the decline of the size of the group of the less-educated, might help explain why less-educated men tend to face higher labor market risks across these different cohorts, as compared 
to intermediate-educated men in the same labor market entry cohort. Labor market risks are measured by unemployment and, if employed, by low socioeconomic status.

We empirically tested several hypotheses. The displacement hypothesis reads that the larger the high-skill supplydemand ratio within an entry cohort, the higher the risk of unemployment versus employment is for the less-educated and the smaller the status differential will be between the less-educated and the intermediate-educated workers. According to the cognitive selection hypothesis, the larger the gap in cognitive ability is in a labor market entry cohort between less-educated and intermediate-educated men, the higher the risk will be of unemployment versus employment and the larger the status differential between less-educated and intermediate-educated men. The discredit hypothesis reads that the smaller the relative size of the low education group is within a labor market entry cohort, the higher will be the unemployment risks of less-educated men compared to the unemployment risk of intermediate-educated men, and the larger the status differential will be between both groups. A final expectation, which we named the negative non-cognitive selection hypothesis, is that the more negatively selective the social composition of the less-educated group is-in terms of parental socioeconomic status-in a given labor market entry cohort, the higher the risk of unemployment will be for less-educated men, as compared to intermediate educated men, and the larger the socioeconomic status differences.

Our comparison of unemployment risks and socioeconomic status across educational groups and labor market entry cohorts showed that only for unemployment risks, the relative position of the less-educated, as compared to the intermediate-educated, deteriorated. For SES the disadvantageous position of the less-educated did neither improve nor worsen.

Not all processes proved to be relevant candidates for explaining the relative increase of unemployment risks of the less-educated. Educational expansion has not resulted in a more negative cognitive selection within the group of less-educated men. Yet, as indicated by the increasing differences in average parental socioeconomic status between the education groups, the social resources of the less-educated group have diminished across cohorts. Furthermore, the oversupply of high-educated workers increased, indicating that displacement might well play a role in explaining an increase in the unemployment risk of the less-educated. The same might hold for the discrediting mechanism: The size of the group of less-educated men in the US strongly declined.

Our multivariate regression analyses showed that a higher relative risk of unemployment for the less educated only increased when negative social selection increased accordingly. Thus, negative social selection provides a structural, new explanation for the increased unemployment risks-of particularly 18 to 30 year old-less-educated men in the United States. Contrary to our expectations, an oversupply of high-educated men did increase unemployment risks for the high-educated themselves, but not for the less-educated. This implies that the increased labor market vulnerability of less-educated men in terms of unemployment risks is not about intensified job competition. It is about negative selection in terms of social resources.

\section{Kurzfassungen}

Die Tatsache, dass schlechter ausgebildete Männer höheren Arbeitsmarktrisiken ausgesetzt sind, wird gemeinhin mit der sogenannten Verdrängungshypothese erklärt. Wenn es ein Überangebot an besser ausgebildeten Arbeitskräften gibt, werden schlechter ausgebildete Arbeitskräfte durch einen Kaskadeneffekt in die einfachsten Tätigkeiten am sekundären Arbeitsmarkt oder sogar in die Arbeitslosigkeit verdrängt. Die Hauptschwäche des Verdrängungsarguments ist, dass hier mögliche Verschiebungen ignoriert werden, die als Ergebnis von Veränderungen im Bildungssystem oder der Bildungsexpansion über Arbeitsmarkt-Eintrittskohorten auftreten. Beispiele solcher Veränderungen beinhalten Prozesse negativer Selektion hinsichtlich der kognitiven und nicht-kognitiven sozialen Zusammensetzung von Gruppen schlechter ausgebildeter Personen sowie Veränderungen der kulturellen Bedeutung, mit der gewisse (niedrige) Bildungsnachweise behaftet sind. Wir vertreten die Ansicht, dass in Erklärungen (langfristiger) Veränderungen in den Beschäftigungsgelegenheiten schlechter ausgebildeter Personen auch diese Verschiebungen berücksichtigt werden müssen.

In diesem Artikel untersuchten wir mittels der wiederholten Querschnitte des US General Social Survey von 1974 bis 2008, inwieweit sich die verbalen Fähigkeiten schlechter ausgebildeter Männer sowie die soziale Zusammensetzung dieser Bildungsgruppe über Arbeitsmarkt-Eintrittskohorten hinweg unterschieden. Des Weiteren haben wir die Ausmaße betrachtet, in welchen diese Unterschiede in der kognitiven und sozialen Zusammensetzung, gemessen an verbaler Aktivität und dem jeweiligen sozioökonomischen Status der Eltern und dem Rückgang der Größe der Gruppe der schlechter ausgebildeten Personen, helfen könnten zu erklären, warum schlechter ausgebildete Männer tendenziell höheren Arbeitsmarktrisiken über diese verschiedenen Kohorten hinweg ausgesetzt zu sein, im Vergleich zu Männern mit einem mittleren Ausbildungsstand in derselben Arbeitsmarkt-Eintrittskohorte. Arbeitsmarktrisiken werden an der Arbeitslosigkeit gemessen und bei Beschäftigten am niedrigen sozioökonomischen Status.

Wir haben verschiedene Hypothesen empirisch untersucht. Die Verdrängungshypothese besagt, dass je größer 
das Nachfrage-Angebotsverhältnis gut ausgebildeter Personen innerhalb einer Eintrittskohorte ist, desto höher ist das Risiko von Arbeitslosigkeit im Verhältnis zu Beschäftigung für die schlechter ausgebildeten Personen und desto kleiner wird der Statusunterschied zwischen den schlechter ausgebildeten Personen und Arbeitskräften mit einem mittleren Ausbildungsstand sein. Die kognitive Selektionshypothese besagt, dass je größer die Lücke in der kognitiven Fähigkeit in einer Arbeitsmarkt-Eintrittskohorte zwischen schlechter ausgebildeten Männern und Männern mit einem mittleren Ausbildungsstand ist, desto höher ist das Risiko von Arbeitslosigkeit im Vergleich zu Beschäftigung und desto größer ist der Statusunterschied zwischen schlechter ausgebildeten Männern und Männern mit einem mittleren Ausbildungsstand. Die Misskreditshypothese besagt, dass je kleiner die relative Größe der schlecht ausgebildeten Gruppe innerhalb einer Arbeitsmarkt-Eintrittskohorte ist, desto höher ist das Arbeitslosigkeitsrisiko schlechter ausgebildeter Männer im Vergleich zum Arbeitslosigkeitsrisiko von Männern mit einem mittleren Ausbildungsstand und desto größer ist der Statusunterschied zwischen den beiden Gruppen. Eine abschließende Annahme, welche wir die negative nichtkognitive Selektionshypothese nennen, ist, dass je selektiv negativer die soziale Zusammensetzung der schlechter ausgebildeten Gruppe - im Hinblick auf den sozioökonomischen Status der Eltern - in einer gegebenen ArbeitsmarktEintrittskohorte ist, desto höher ist das Risiko von Arbeitslosigkeit von schlechter ausgebildeten Männern im Vergleich zu Männern mit einem mittleren Ausbildungsstand und desto größer sind die sozioökonomischen Statusunterschiede.

Unser Vergleich von Arbeitslosigkeitsrisiken und sozioökonomischem Status über Bildungsgruppen und Arbeitsmarkt-Eintrittskohorten hinweg hat gezeigt, dass sich nur bei den Arbeitslosigkeitsrisiken die relative Position der schlechter ausgebildeten Personen im Vergleich zu Personen mit einem mittleren Ausbildungsstand verschlechtert hat.
Im Hinblick auf den sozioökonomischen Status hat sich die nachteilige Position der schlechter ausgebildeten Personen weder verbessert noch verschlechtert.

Nicht alle Prozesse haben sich als relevante Kandidaten für die Erklärung des relativen Anstiegs des Arbeitslosigkeitsrisikos schlechter ausgebildeter Personen erwiesen. Die Bildungsexpansion hat nicht zu einer negativeren kognitiven Selektion innerhalb der Gruppe der schlechter ausgebildeten Männer geführt. Trotzdem sind die sozialen Ressourcen der schlechter ausgebildeten Gruppe, wie angedeutet durch die steigenden Unterschiede im durchschnittlichen sozioökonomischen Status der Eltern zwischen den Bildungsgruppen, über Kohorten geschrumpft. Des Weiteren ist das Überangebot an gut ausgebildeten Arbeitskräften gestiegen, was darauf hindeutet, dass Verdrängung in der Erklärung des Anstiegs des Arbeitslosigkeitsrisikos schlechter ausgebildeter Personen eine Rolle spielen könnte. Dasselbe könnte für den Misskreditsmechanismus gelten: Die Größe der Gruppe der schlechter ausgebildeten Männer in den USA ist stark zurückgegangen.

Unsere multivariaten Regressionsanalysen haben gezeigt, dass ein höheres relatives Arbeitslosigkeitsrisiko schlechter ausgebildeter Personen nur anstieg, wenn negative soziale Selektion entsprechend angestiegen ist. Daher bietet negative soziale Selektion eine strukturelle, neue Erklärung für ein gestiegenes Arbeitslosigkeitsrisiko - von insbesondere 18- bis 30-jährigen - schlechter ausgebildeter Männer in den USA. Entgegen unserer Erwartungen hat ein Überangebot an gut ausgebildeten Männern das Arbeitslosigkeitsrisiko der gut ausgebildeten selbst gesteigert, aber nicht das der schlechter ausgebildeten Männer. Das legt nahe, dass die gestiegene Vulnerabilität schlechter ausgebildeter Männer auf dem Arbeitsmarkt bezüglich Arbeitslosigkeitsrisiken nicht auf einen verstärkten beruflichen Wettbewerb zurückzuführen ist, sondern auf negative Selektion bezüglich sozialer Ressourcen.

\section{Appendix}

Table 4 Correlations between cohort-replacement variables $(N=35)$

\begin{tabular}{lcccc}
\hline & $\begin{array}{l}\text { High-skill supply- } \\
\text { demand ratio }\end{array}$ & $\begin{array}{l}\text { Negative selection } \\
\text { on verbal abilities }\end{array}$ & $\begin{array}{l}\text { Less-educated } \\
\text { group's size }\end{array}$ & $\begin{array}{l}\text { Negative selection } \\
\text { on parental SES }\end{array}$ \\
\hline High-skill supply-demand ratio & 1.00 & & \\
Negative selection on verbal abilities & 0.10 & 1.00 & 1.00 \\
Less-educated group's size & $-0.32 \sim$ & 0.25 & $-0.31 \sim$ \\
Negative selection on parental SES & 0.03 & -0.13 & 1.00 \\
\hline
\end{tabular}

Level of significance: $\sim p<0.10 ;{ }^{*} p<0.05 ;{ }^{* *} p<0.01$

Source: Authors' calculations; General Social Survey 1974-2008 


\section{References}

Autor, D.H., Levy, F., Murnane, R.J.: The skill content of recent technological change. Q. J. Econ. 118(4), 1279-1333 (2003)

Alwin, D.F., McCammon, R.J.: Aging versus cohort interpretations of intercohort differences in GSS vocabulary scores. Am. Sociol. Rev. 64, 272-286 (1999)

Arrow, K.J.: Models of discrimination. In: Arrow, K.J. (ed.) Collected Papers of Kenneth J. Arrow, pp. 89-111. Harvard University Press, Cambridge (1985)

Becker, G.S.: Human Capital. National Bureau of Economic Research, New York (1964)

Bell, D.: The Coming of Post-Industrial Society. Heinemann, London (1974)

Berg, I.: Education and Jobs: The Great Training Robbery. Beacon Press, Boston (1971)

Bills, D.B.: The mutability of educational credentials as hiring criteria. Work Occup. 19, 79-95 (1992)

Blau, P., Duncan, O.D.: The American Occupational Structure. John Wiley, New York (1967)

Blossfeld, H.-P.: Bildungsexpansion und Berufschancen. Campus, Frankfurt (1985)

Blossfeld, H.-P.: Changes in educational careers in the Federal Republic of Germany. Sociol. Educ. 63, 165-177 (1990)

Bluestone, B., Harrison, B.: The growth of the low-wage employment: 1963-86. Am. Econ. Rev. 78, 124-128 (1988)

Bose, C.E., Rossi, P.H.: Gender and jobs: prestige standings of occupations as affected by gender. Am. Sociol. Rev. 48, 316-330 (1983)

Boudon, R.: Education, Opportunity, and Social Inequality. Wiley, New York (1974)

Bourdieu, P.: Distinction: A Social Critique of the Judgment of Taste. Harvard University Press, Cambridge (1987)

Bowles, S., Gintis, H., Osborne, M.: The determinants of earnings. J. Econ. Lit. 39, 1137-1176 (2001)

Bowles, S., Gintis, H.: Schooling in Capitalist America. Routledge, London (1976)

Breen, R., Goldthorpe, J.H.: Explaining educational differentials. Ration. Soc. 9, 275-305 (1997)

Cappelli, P.: Are skill requirements rising? Ind. Labor Relat. Rev. 46, 515-530 (1993)

Cappelli, P.: Is the "skills gap" really about attitudes. Calif. Manag. Rev. 37, 108-124 (1995)

Collins, R.: The Credential Society. Academic Press, New York (1979)

Erikson, R., Jonsson, J.O.: Introduction: explaining class inequality in education. In: Erikson, R., Jonsson, J.O. (eds.) Can Education Be Equalized? pp. 1-63. Westview, Boulder (1996)

Farkas, G.: Cognitive skills and noncognitive traits and behaviors in stratification processes. Annu. Rev. Sociol. 29, 541-562 (2003)

Fiske, S.T.: Stereotyping, prejudice, and discrimination. In: Gilbert, D.T., Fiske, S.T., Lindzey, G. (eds.) Handbook of Social Psychology, 4th edn., pp. 357-411. McGraw-Hill, New York (1998)

Freeman, R.B.: The Overeducated American. Academic Press, New York (1976)

Ganzeboom, H.B.G., De Graaf, P.M., Treiman, D.J.: A standard international socio-economic index of occupational status. Soc. Sci. Res. 21, 1-56 (1992)

Gesthuizen, M.: Job characteristics and voluntary mobility in the Netherlands: differential education and gender patterns? Int. J. Manpow. 30, 549-566 (2009)

Gesthuizen, M., Kraaykamp, G.: Verbal ability of low-educated people in the Netherlands. Neth. J. Soc. Sci. 38, 191-211 (2002)

Gesthuizen, M., De Graaf, P.M., Kraaykamp, G.: The changing family background of the low-educated in the Netherlands. Eur. Sociol. Rev. 21, 441-452 (2005)

Gesthuizen, M., Scheepers, P.: Economic vulnerability among loweducated Europeans: resource, composition, labour market and welfare state influences. Acta Sociol. 53, 247-267 (2010)
Gesthuizen, M., Solga, H., Künster, R.R.: Context Matters: Economic marginali-sation of low-educated workers in cross-national perspective. Eur. Sociol. Rev. 27(2), 264-280 (2011)

Gesthuizen, M., Wolbers, M.H.J.: Are low educated men subject to structural or cyclical crowding out? Employment transitions in the Netherlands from 1980 to 2004. Res. Soc. Stratif. Mobil. 28, 437$451(2010)$

Glenn, N.D.: Cohort Analysis. Sage, Beverly Hills (1977)

Goffman, E.: Stigma. Prentice-Hall, Englewood Cliffs (1963)

Goldin, C., Katz, L.F.: The Race Between Education and Technology. Belknap Press, Cambridge (2008)

Granovetter, M.: Getting a Job. Harvard University Press, Cambridge (1974)

Hakim, C.: Key Issues in Women's Work: Female Heterogeneity and the Polarisation of Women's Employment. Athlone Press, London (1996)

Harrison, B., Weiss, M.: Labor market restructuring and workforce development. In: Giloth, R.P. (ed.) Jobs and Economic Development, pp. 19-41. Sage, London (1998)

Heckman, J.J., Rubinstein, Y.: The importance of noncognitive skills. Am. Econ. Rev. 91, 145-149 (2001)

Hirsch, F.: Social Limits to Growth. Harvard University Press, Cambridge (1977)

Jones, E.E., Farina, A., Hastorf, A.H., Markus, H., Miller, D.T., Scott, R.A.: Social Stigma: The Psychology of Marked Relationships. W.H. Freeman, New York (1984)

Kalleberg, A.L.: Changing contexts of careers. In: Kerckhoff, A.C. (ed.) Generating Social Stratification, pp. 343-358. Westview, Boulder (1996)

Kerr, C., Dunlop, J.T., Harbison, F., Myers, C.A.: Industrialism and Industrial Man. Harvard University Press, Cambridge (1960)

Levy, F., Murnane, R.: U.S. earnings and earnings inequality. J. Econ. Lit. 30, 1333-1381 (1992)

Lin, N.: Social networks and status attainment. Annu. Rev. Sociol. 25, 467-487 (1999)

Livingstone, D.W.: The Education-Jobs Gap. Westview, Boulder (1998)

Mason, K.O., Mason, W.M., Winsborough, H.H., Poole, W.K.: Some methodological issues in cohort analysis of archival data. Am. Sociol. Rev. 38, 242-258 (1973)

Menard, S.: Longitudinal Research. Sage, Newbury Park (1991)

Meyer, J.W.: The effects of education as an institution. Am. J. Sociol. 83, 55-77 (1977)

Miner, J.B.: Intelligence in the United States. Springer, New York (1957)

Parsons, T.: The school class as a social system. Harv. Educ. Rev. 29, 297-318 (1959)

Pollmann-Schult, M.: Crowding-out of unskilled workers in the business cycle. Eur. Sociol. Rev. 21, 467-480 (2005)

Rosenbaum, J.A., Binder, A.: Do employers really need more educated youth? Sociol. Educ. 70, 68-85 (1997)

Shavit, Y., Blossfeld, H.-P. (eds.) Persistent Inequality: Changing Educational Attainment in Thirteen Countries. Westview, Boulder (1993)

Solga, H.: Stigmatisation by negative selection. Eur. Sociol. Rev. 18, 159-178 (2002)

Solga, H.: Lack of training-the employment opportunities of lowskilled persons from a sociological and micro-economic perspective. In: Mayer, K.U., Solga, H. (eds.) Skill Formation, pp. 173204. Cambridge University Press, New York (2008)

Sørensen, A.B.: The structure of inequality and the process of attainment. Am. Sociol. Rev. 42, 965-978 (1977)

Sørensen, A.B., Kalleberg, A.L.: An outline of a theory of matching persons to jobs. In: Berg, I. (ed.) Sociological Perspectives on Labor Markets, pp. 49-74. Academic Press, New York (1981) 
Spence, M.A.: Market Signaling. Harvard University Press, Cambridge (1974)

Thorndike, R.L.: The screening tests of verbal intelligence. J. Appl. Psychol. 26, 128-135 (1942)

Thurow, L.C.: Generating Inequality. Basic Books, New York (1975)

Thurow, L.C.: A job competition model. In: Piore, M.J. (ed.) Unemployment and Inflation, pp. 17-32. M.E. Sharpe, New York (1979)

Tilly, C.: Durable Inequality. University of California Press, Berkeley (1998)

Tomaskovic-Devey, D.: The gender and race composition of jobs and the male/female, white/black pay gaps. Soc. Forces 72, 45-76 (1993)

Treiman, D.J.: Industrialization and social stratification. In: Laumann, E. (ed.) Social Stratification, Research and Theory for the 1970s, pp. 207-234. Bobbs-Merill, Indianapolis (1970)

Wanner, R.A.: Twentieth-century trends in occupational attainment in Canada. Can. J. Sociol. 30, 441-469 (2005)

Weiss, A.: Human capital vs. signalling explanations of wages. J. Econ. Perspect. 9, 133-154 (1995)

Wilson, W.J.: The Truly Disadvantaged: The Inner City, the Underclass, and Public Policy. University of Chicago Press, Chicago (1990)

Wolbers, M.H.J., De Graaf, P.M., Ultee, W.C.: Trends in the occupational returns to educational credentials in the Dutch labor market. Acta Sociol. 44, 5-19 (2001)
Dr. Maurice Gesthuizen is an Assistant Professor in the Department of Sociology, Radboud University Nijmegen, the Netherlands. He is interested in educational inequality, economic vulnerability, social capital and their interrelationships. He studies these topics in longitudinal and comparative perspective and has published in international journals such as Acta Politica, Acta Sociologica, the European Sociological Review, International Sociology, Nonprofit and Voluntary Sector Quarterly, Research in Social Stratification and Mobility, Scandinavian Political Studies, Social Science Research, Sociology of Health \& Illness, and Work, Employment \& Society.

Prof. Dr. Heike Solga is head of the research unit "Skill Formation and Labor Markets" at the WZB and professor of sociology at the Freie Universität Berlin. She is head of the "College of Interdisciplinary Educational Research", a joint initiative of the German Ministry of Education and Science (BMBF), the Jacobs Foundation and the Leibniz Association (www.ciderweb.org). Her research interests are life-course research, educational and labor market inequalities, and educational deprivation. Among her recent publications are "How low-achieving German youth beat the odds and gain access to vocational training-Insights from within-group variation" (together with B. Kohlrausch, European Sociological Review, 2012, advanced access), "Context matters: Economic marginalisation of low-educated workers in cross-national perspective" (together with M. Gesthuizen and R. Künster, European Sociological Review, 2011). 